\title{
Internal and External Factors Leading to Corporate Financial Distress A Case Study of Huayi Brothers Media Group
}

\author{
Ye Lu*, Yubo Li, Haomin Zhang, Yilu Kou \\ Accounting department, SHU-UTS SILC Business School, Shanghai University
}

DOI: $10.36348 /$ sjef.2020.v04i06.014

| Received: 15.06.2020 | Accepted: 22.06.2020 | Published: 24.06.2020

*Corresponding author: $\mathrm{Ye} \mathrm{Lu}$

\section{Abstract}

The companies that experienced financial distress may have high possibilities of financial bankruptcy. Thus, understanding underlying factors that lead to financial distress is critical to both shareholders and investors. This paper built a conceptual framework and uses this to analyze the financial distress of one of the most famous public company in Chinese entertainment industry: Huayi Brothers. This paper found that internal factors like aggressive investment, high financial leverage, inappropriate business strategy and external factors as change of accounting standard and tightening monetary policy may lead to the financial distress of the case company.

Keywords: Corporate Financial Distress.

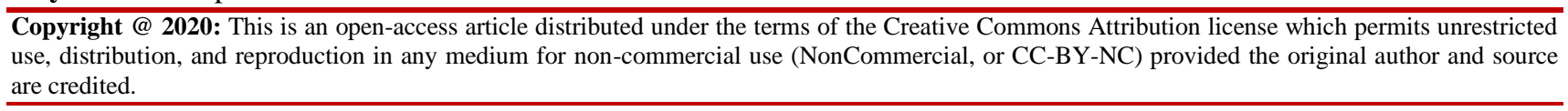

\section{INTRODUCTION}

Financial distress, also known as "financial crisis" or "financial difficulties". From the point of view of preventing financial distress, the definition of financial distress is the phenomenon that a company's operating cash flow is not enough to cover the existing debt due. It is worth noting that financial distress is not synonymous with financial bankruptcy. Most financial bankrupt corporations have experienced financial distress, but there are also some corporations that have experienced financial distress could get through the crisis by asset restructuring. There are many factors that cause corporation to fall into financial distress, such as poor operation and management but there also some external factors such tightening monetary policy.

The corporation bonds used to be very "safe" in Chinese bond market as none of corporation bond had default. However, in 2014, the first bond default in Chinese financial market and following central government's "deleveraging" policy, more and more corporation bonds default. What factors leading to the company's financial distress in Chinese context? Not only investors but also academic scholars have started to investigate the underlying reasons of financial distress.

The structure of this paper is as follows: section two reviews some existing literatures about financial distress and build the analytic framework of the case company; section three is the main part of this paper and include the background information of the case company and the analysis of why it fell into financial distress in 2018; this paper is closed with a short summary in section four.

\section{LITERATURE REVIEW}

Altman [1] defined financial distress as the company that is in the bankruptcy proceedings. But Deakin [2] did not agree with him, he thought financial distress means the company has already experienced bankruptcy and could not repay its debts. Some other authors like Carmichael [3] thought those companies that could afford its debt or has liquidation problem could be regarded as in a financial distress. In this paper, we thought financial distress is not interchangeable with financial bankruptcy, but it is a warning to that company which has liquidation problem. Some authors argue that financial distress is not happening in a couple of days but is a changing process [4]. There are lots of authors who has keen to find an optimal forecasting model to predict the financial distress. $\mathrm{Wu}$ and $\mathrm{Lu}$ [5] classified these models into three groups: forecasting model with financial ratios, forecasting models with cash analysis and forecasting models with stock returns. Some other researchers tested the causal relationship between a specific factor and financial distress. Jiang, Zhang, Lu and Chen [6] collected the data of all listed companies in Chinese market and found that the overconfidence of 
management team and their aggressive expansion strategy will increase the possibility of financial distress for those companies. Apart from the empirical tests, some researchers analyze the factors that lead companies to financial distress from conceptual perspective. Xie [7] introduced a Japanese study and found that bad management lead to the deterioration of financial structure and this leads to the increasing of debe ratio and decrease of financial solvency. Argenti [8] did some case studies and found that the factors that lead to financial distress include: bad operation, insufficient accounting information, inappropriate adaption policy to business changes, factors that restrict companies quick reaction to changes in business environment, aggressive operation, invest too many big projects, high financial leverage and common operation risks. By reviewing the previous studies $[7,8,5,4]$ and relating then to Chinese context, we build a conceptual framework that could be used to analyze the internal and external factors that may lead companies to financial distress, as shown in figure 2

The internal factors that may lead the companies into financial distress

- Whether the investment that made by the company is aggressive or not. Aggressive investments may cause the problem of cash shortage or high financial leverage.

- Whether the financial leverage is too high. Too much debt will significantly increase company's interest payments every year and increase the risk of solvency.

- Whether the company has the internal control problem or no. The unclear authority and responsibility will cause the fund utilization efficiency to be too low.

- Whether the company's governance structure is not as good as expected. The conflicts between management and shareholder's interests maybe server and the management team may be pursing short-term profits and under week monitoring.

- Whether the strategy of the company is inappropriate. For instance, the company may set a long-term strategy which is unrealistic and that may induce company's excessive operation.

The external factors that lead the company into financial distress

- Whether the state policies, laws or regulations may have negative impact on the company's daily operation. For example, the change of tariff may have significant impact on the operation of import and export corporations.

- Whether the macroeconomic environment depressed.

- Whether monetary policy will be tightened and whether it will be difficult for companies to raise funds by issuing bonds or applying for a loan.

- Whether the revision of the accounting standards might have a great impact on the calculation of profits.

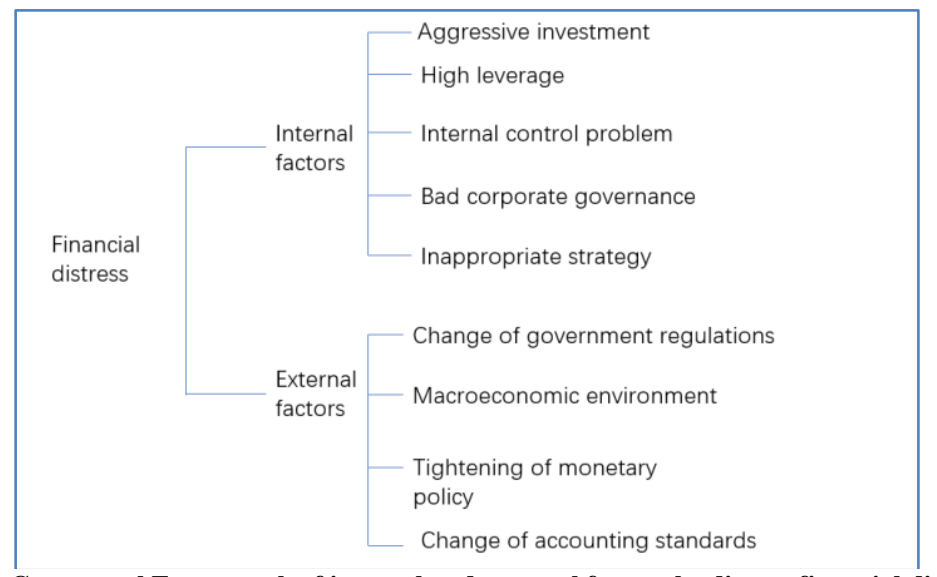

Fig-2: Conceptual Framework of internal and external factors leading to financial distress

\section{EMPIRICAL EVIDENCE \\ Background information}

Huayi Brothers was founded in 1994 by brothers Wang Zhongjun and Wang Zhonglei. In 2000, Huayi started its business of stars' management, and became one of the most senior star management firms. In the year of 2016, Huayi brothers earned nearly 2.6 billion yuan in box office receipts with their two blockbuster films, "The Lost Legend of the Dragon" and "Lao Pao Er", both of which were released during Spring Festival movie season, making Huayi the biggest winner of the year. On September 27, 2009, it became the first entertainment company to be allowed to issue shares in the public market after being approved by the Securities and Futures Commission (CSRC). In addition to its original business scale of movie making and star management, from 2011, Huayi began to broaden its business map. In 2011, Huayi brothers began to expand its business to live entertainment and committed to integrating culture, film and television, internet and tourism resources to create a new film culture tourism industry. Apart from that, Huayi also expanded its business to internet related products including new media, online games, fan economy and VR technology. 
On $30^{\text {th }}$ October, 2009, Huayi Brothers officially listed on the Shenzhen Stock Exchange, trading under the ticker symbol 300027, with an issue price of 28.58 yuan per share. The trading volume of Huayi reached 29,611,563 shares on the day of issue, with the highest trading price reached to 91.8 yuan per share and closing price of 70.81 yuan per share. Its over-reliance on film and star management businesses led Huayi, the company which just went public, to its first crisis in 2009. In the two years from 2009 to 2010 , nearly 50 people including Wang Jinghua, the mainland's famous star agent, left Huayi. At that time, Wang Zhongjun (the founder of Huayi Brothers) realized the problem and proposed the goal of "demonetizing film". On the one hand Huayi tried to keep some famous actors and directors, including Feng Xiaogang. On the other hand, Huayi tried to broaden its career blueprint through a large number of acquisitions. However, the strategy of "de-monetizing films" has not helped Huayi to expand to other businesses. Instead, it has taken a hit to its once-thriving film business. In 2014, Huayi only had 2 percent share of film distribution. On $22^{\text {nd }}$ October, 2015, Huayi Brothers announced that it plans to acquire $70 \%$ shares of a company called Dongyang Haohan whose main business is star management with the trading price of 756 million yuan. The premium of this trade was more than 100 times and Huayi generated goodwill of 749 million RMB on the books after this trading. In November 2015, Huayi brothers acquired $70 \%$ percent shares of Dongyang Meila which was owned by the famous director Feng Xiaogang and Lu Guoqiang with the trading price of 1.05 billion yuan. The premium of this trade reached to 110,000 times. The purpose of these two acquisitions is to keep some famous actors and directors in Huayi and expect them to generate more profits for Huayi in the future. Apart from these two acquisitions, Huayi also acquire one South Korean star management company and some online game companies. From 2010 to 2016, Huayi had made eight acquisitions to expand its business, as shown in table 1 . This overexpansion has given Huayi brothers nearly 3 billion RMB goodwill on its book and set the stage for its financial crisis.

Table-1: eight biggest acquisitions of Huayi Brothers from 2010 to 2016

\begin{tabular}{|c|c|c|c|c|c|}
\hline & $\begin{array}{l}\text { Acquired } \\
\text { time }\end{array}$ & Acquired company & $\begin{array}{l}\text { Trading } \\
\text { price }\end{array}$ & Premium & Intension of Acquisition \\
\hline 1 & 2010.12 .08 & $\begin{array}{l}\text { Beijing Huayi Juren } \\
\text { techonology Limited Company }\end{array}$ & $\begin{array}{l}70 \text { million } \\
\text { Yuan }\end{array}$ & 5.6 times & Enter network game industry \\
\hline 2 & 2013.09.10 & $\begin{array}{l}\text { Zhejiang Changsheng Film } \\
\text { making company }\end{array}$ & $\begin{array}{l}252 \text { million } \\
\text { yuan }\end{array}$ & 36 times & $\begin{array}{l}\text { Keep famous movie stars which } \\
\text { are also the shareholders of } \\
\text { Changsheng Company }\end{array}$ \\
\hline 3 & 2014.05.16 & $\begin{array}{l}\text { Guangzhou Yinhang } \\
\text { Technology Company }\end{array}$ & $\begin{array}{l}671.616 \\
\text { Million } \\
\text { Yuan }\end{array}$ & 15.9 times & $\begin{array}{l}\text { Expand it business in network } \\
\text { game industry }\end{array}$ \\
\hline 4 & 2015.09.01 & $\begin{array}{l}\text { Tianjing Huanyan Advertising } \\
\text { Company }\end{array}$ & $\begin{array}{l}250 \text { Million } \\
\text { Yuan }\end{array}$ & 25 times & $\begin{array}{l}\text { Expand its business in design } \\
\text { and advertisements }\end{array}$ \\
\hline 5 & 2015.10.22 & $\begin{array}{l}\text { Zhejiang Dongyang Haohan } \\
\text { Entertainment Company }\end{array}$ & $\begin{array}{l}756 \text { Million } \\
\text { Yuan }\end{array}$ & 108 times & Keep famous movie stars \\
\hline 6 & 2015.11.24 & $\begin{array}{l}\text { Beijing Huayuan Jiali Real } \\
\text { Estate company }\end{array}$ & $\begin{array}{l}243.14 \\
\text { Million } \\
\text { Yuan }\end{array}$ & 1.25 times & Enter the real estate industry \\
\hline 7 & 2015.12.09 & $\begin{array}{l}\text { Zhejiang Dongyang Meila } \\
\text { Entertainment Company }\end{array}$ & $\begin{array}{l}\text { 1.05 Billion } \\
\text { Yuan }\end{array}$ & $\begin{array}{l}110,000 \\
\text { times }\end{array}$ & $\begin{array}{l}\text { Keep the famous director Feng } \\
\text { Xiaogang }\end{array}$ \\
\hline 8 & 2016.02.29 & $\begin{array}{l}\text { Beijing Yingxiong Huyu } \\
\text { Technology Company }\end{array}$ & $\begin{array}{l}1.9 \text { Billion } \\
\text { Yuan }\end{array}$ & 91.5 times & $\begin{array}{l}\text { Expand its business in network } \\
\text { gave and software development }\end{array}$ \\
\hline
\end{tabular}

In the mid of 2018, one of Chinese famous TV presenters Cui Yongyuan raised the issue of "Dual contracts". He said most of movie stars signed two contracts with film making company. The one with the lower payment was used to submit to tax authorities and the other one show the actual payments that the movie stars get, which is significantly higher than the number on the other contract. He also claimed that he had already collected the evidence to prove that almost 585 artists who had cooperated with Huayi Brothers had signed this kind of "Dual contract". Cui Yongyuan's revelations attracted the attention of tax authorities. After the investigation, Jiangsu Tax Bureau ordered one of the artists who had cooperated with Huayi many times to pay a fine of 880 million yuan. Although Huayi Brothers has repeatedly clarified that it has no tax problem, but it seems that investors in the open market do not buy that. Huayi brothers share price swoon. On 9th Oct, 2018, Huayi brothers' share price was less than 5 yuan and its market value had dropped by nearly 80 percent from its peak of 80 billion yuan.

The third-quarters numbers of Huayi show that it had a good will of 3.06 billion yuan on its book. In 2018, the Accounting Standards Committee of the Ministry of Finance proposed that the goodwill of public company may need to be amortized in the future. This information hit the companies like Huayi very hard 
and Huayi has to prepare for this change and do its goodwill impairment beforehand.

On $24^{\text {th }}$ December, 2019, China Chengxin International Credit Rating company announced that it decide to downgrade Huayi Brothers' credit rating to AA and include the bonds issued by Huayi named "16 Huayi Brothers MTN001" (due on $28^{\text {th }}$ Jan, 2019) and "18 Huayi Brothers CPO01" (due on $9^{\text {th }}$ April, 2019) to its "watch list". China Chengxin International Credit Rating Company also said that it would continue to pay attention to the company's repayment fund arrangements and its goodwill problem. On the afternoon of $24^{\text {th }}$ Dec, 2019, the return of equity of Huayi dropped significantly and its CAR had decreased to $-3.47 \%$. Some implicit credit rating agencies downgrade the bond "MTN 001" from A- to C in two weeks. This indicates that these agencies believe that the possibilities of bond default are over $45 \%$.

\section{CASE ANALYSIS}

\section{Internal reasons}

\section{Many high premium $M \& A$, pricing risk and} financing risk appearing

Since 2011, Huayi Brothers has made eight major acquisitions. Looking at Huayi Brothers' eight acquisitions, we can see that Huayi brothers' acquisition focus is mainly on expanding its online gaming territory and stabilizing its star management business. Huayi Brothers' eight acquisitions were all at a premium, with a premium of up to 108 times for Zhejiang Dongyang Haohan Entertainment Company and 110,000 times for Zhejiang Dongyang Meila Entertainment Company. The acquisition of Dongyang Haohan gave Huayi Brothers 740 million yuan of goodwill on its books, while the acquisition of Dongyang Meila brought more than 1billion yuan of goodwill on Huayi's books.

After all, Huayi brothers' financial difficulties are essentially a cash flow problem. Since 2015, Huayi brothers' net cash flow from operating activities can no longer support the cash flow required for many highpremium acquisitions. In addition to a stock offering in August 2015 that raised 3.573 billion yuan, Huayi raised money through bank loans and debt financing channels. Due to the increase in debt financing, Huayi brothers financial costs increased, debt service pressure increased rapidly. The pressure burst in late 2018 .

\section{Slow development of business strategy, the main business lost its core competitiveness}

Since 2016, Huayi brothers have been sticking to four main business areas, namely film and entertainment, brand licensing and reality entertainment, Internet Entertainment, Industry Investment and Industry-related equity investment. Film and entertainment business has been in a leading position. Its business contents mainly include film production, film distribution business; television production and distribution; actor/actress management and related Services; Cinema Investment, Management, operation and other business and the sales of digital projection equipment. Facing the risk of film and Television Industry, the effective way to reduce the risk is to make the whole industrial chain layout. Light Media, for example, owns more than $50 \%$ of Maoyans' shares, an online ticketing platform that can influence movie scheduling. Wanda film, for example, has nearly 500 theaters and more than 4,000 screens nationwide. Huayi brothers have only 20 cinemas and 200 screens in China. Huayi Brothers tried to keep Feng Xiaogang, a well-known director in China, by buying Dongyang Meila. However, on $29^{\text {th }}$ Nov 2012, Feng Xiaogang's film '1942' fell short of expectations on its release day, wiping 1.3 billion yuan off Huayi's market value in two trading day's from30th of November. The first time Feng Xiaogang's gold medal has failed to materialize.

Huayi Brothers has been trying to break away from a single source of revenue and profits. However, the film and Television Entertainment Business has always been the main contributor of Huayi brothers' revenue, due to the slow investment in other business scales like brand licensing and real-life entertainment business and Internet entertainment. As a result, Huayi Brothers' plan of "de-monetizing film" had not been success and on the contrary, it lost its leading position in the film industry compared to its rivals like Light Media and Wanda Films.

\section{The financial structure is out of balance and there is great pressure to repay debts}

In the long run, asset-liability ratio is the ratio of total liabilities to total assets. The higher it is, the higher the financial risk of the enterprise is. However, it is not the case that the lower the leverage ratio, the better. The enterprise that uses appropriate debt leverage may enhance the enterprise shareholders' wealth. Huayi Brothers' asset-liability ratio has been kept around $50 \%$. Although it is within a moderate range, compared with other film and television entertainment enterprises, its asset-liability ratio is still high.

Since 2016, Huayi brothers' interest-bearing debt ratio has remained high, which is above $60 \%$. Under normal circumstances, when the interest-bearing debt ratio is higher than $60 \%$, the company has a great probability of financial distress. Huayi brothers' interest-bearing debt ratio in 2016,2017 and 2018 have always been more than $60 \%$ which means it has fallen into financial distress ever since then.

In the short term, the net cash flow from operating activities of Huayi Brothers has always been unable to meet the needs of repaying current liabilities. Moreover, it needed continuous raising capital to support the operation of the enterprise. Liquid assets refer to the assets with strong liquidity in an enterprise. At the end of 2018, the Liquid assets of Huayi Brothers 
Ye Lu et al., Saudi J Econ Fin, June., 2020; 4(6): 281-286

were significantly lower than the number of current liabilities, indicating that Huayi Brothers was under

great short-term debt repayment pressure at that time.

Table-2: Short-term debt paying ability of Huayi Brothers from 2014 to 2018 in billions

\begin{tabular}{|l|r|r|r|r|r|}
\hline & $\mathbf{2 0 1 4}$ & $\mathbf{2 0 1 5}$ & $\mathbf{2 0 1 6}$ & \multicolumn{1}{c|}{$\mathbf{2 0 1 7}$} & \multicolumn{1}{c|}{$\mathbf{2 0 1 8}$} \\
\hline Current liabilities & 2.9 .3 & 5.962 & 5.938 & 5.044 & 7.257 \\
\hline Net operating cash flow & -0.021 & 0.527 & 0.759 & -0.215 & 0.582 \\
\hline Liquid assets & 3.497 & 5.417 & 7.104 & 6.162 & 4.395 \\
\hline
\end{tabular}

In addition, Huayi Brothers' total market value dropped from a peak of 85.9 billion yuan in 2015 to 12.2 billion yuan on the last trading day of 2018 . Falling share prices have made Chairman Wang Zhongjun reluctant to use additional equity issuance as a means of financing. In addition to bank borrowing and bond issuance, Mr. Wang Zhongjun and Mr. Wang Zhonglei have already pledged as many shares as possible. By the end of 2018, Wang Zhongjun has pledged 568 million shares of 615 millions, accounting for $92.3 \%$ of the total. Wang Zhonglei holds about 172 million shares, of which 168 million have been pledged, accounting for 97.8 percent. At the same time, Huayi Brothers' shares has been continuously falling, increasing the liquidation risk.

\section{EXTERNAL REASONS}

\section{Financial Policy Tightens, companies struggle to raise capital}

Under the background of financial deleveraging, financial companies should return to their essence and provide funds for the real economy, instead of idling in financial institutions. As a result, the economy as a whole is contracting credit. The direct effect of this is that financial institutions are more constrained in their lending, and companies have to reduce their debt levels. For these years, Huayi Brosthers has been continuously issuing short-term debt to support its long-term acquisition investment. However, under austerity, borrowing new money to pay off old debts is no longer sustainable. As a result, corporate liquidation risk has always been at a very high level.

\section{Investment Surplus, goodwill bubble appears}

"No acquisition, no goodwill. ". Goodwill comes from acquisitions. If an offer price exceeds the fair value of the net assets of the target, the excess part is called goodwill. According to regulations, the goodwill assets of listed companies must be tested for impairment every year. If the acquired objects show signs of deterioration, the listed companies must reduce the value of goodwill. If the scale of impairment is too large, it will greatly affect the performance of listed companies.

In 2018, the problem of goodwill impairment broke out in the annual report of listed companies. There are two reasons for this. On the one hand, in November 2018, the CSRC issued accounting regulatory risk tips No. 8 -- A decline in goodwill. This strictly and explicitly requires enterprises to regularly or timely do goodwill impairment test, at least do the test once at the end of every year. On the other hand, in January 2019, an expert from the Accounting Standards Board of the Ministry of Finance proposed that goodwill should be amortized year by year instead of impairment. This "policy expectation" led to many public companies to record its impairment losses in 2018. Public companies were trying to get rid of the huge burden of goodwill as soon as possible. According to the regulation of CSRC, the company which has made loss for consecutive three years will be de-listed. If the policy of "goodwill amortization" is passed, a lot of public companies may be de-listed because of not having enough profits to cover amortization expenses.

Huayi Brothers has recorded a total of 973 million yuan in goodwill impairment provision in 2018 , accounting for 89 percent of its net loss of 1.093 billion yuan. This means that most of Huayi brothers' operating losses in 2018 were due to the provision for impairment of goodwill. This is also the first time Huayi brothers impair its goodwill. However, even so, the balance of book value of goodwill after impairment was still 2.096 billion, accounting for $11.37 \%$ of total assets.

\section{CONCLUSION}

With the application of "deleveraging" policy in Chinese financial markets, more and more companies may experience financial distress or financial difficulties in these years. In order to choose investment that matches their risk preference, investors should understand the underlaying reasons that lead to financial distress. This paper built a conceptual framework and applies the framework to analyze the financial distress case: Huayi Brothers. This paper found that, aggressive investments and inappropriate business strategy made by Huayi Brothers lead to its shortage of cash and significantly increase its goodwill. Huayi Brothers has to continuously raise fund by issuing bonds or applying for debts. This result in great pressure of repaying debts to Huayi Brothers. Although Huayi Brothers has got through this financial distress now but over $90 \%$ of its shares have been pledged and essentially, its business is no longer under the control of Wang's Brothers. 


\section{REFERENCE}

1. Altman, E. I. (1968). Financial ratios, discriminant analysis and the prediction of corporate bankruptcy. The journal of finance, 23(4), 589-609.

2. Deakin, E .B. (1972).“A Discriminant Analysis of Prediction of Business Failure", Journal of Accounting Research (Spring), 167-169.

3. Carmichael, R. (1972). The auditor's reporting obligation. Published American Institute.

4. Changjiang, L., Lili, X., \& Lin, Z. (2004). Comparative Analysis of Corporate Financial
Distress and Financial Bankruptcy [J]. Economic Research Journal, 8, 64-73.

5. Wu, S., \& Lu, X. (2001). A study of models for predicting financial distress in China's listed companies. Economic Research Journal, 6, 46-55.

6. Shinong, W., \& Xianyi, L. (2001). A Study of Models for Predicting Financial Distress in China's Listed Companies [J]. Economic Research Journal, 6, 46-55.

7. Xie, K. (2001). Survival risks of corporations, First Edition, Economic Management Press: Beijing

8. Argenti, J. (1976). Corporate Collapse: The Cause and Symptoms. McGrawOHill, New York. 